of leaving the ministry. His study reveals significant results in a group of pastors posing as possible risk for leaving the ministry, as well as a group of pastors that will function optimally within the RCSA. Interestingly, his study finds that the Phlegmatic personality type has the largest representation among ministers in the RCSA, while the Sanguine and Melancholic personality types have the lowest representations.

In a stimulating article, Jan-Albert van den Berg provides critical-evaluative auto-ethnographic reflections on the recording and conducting of a digital (YouTube) worship service in the wake of the COVID-19 pandemic. He sensitively considers, from a practical theology perspective, the possible significance of perspectives for future worship practices of communities of faith.

\section{Forgiveness and reconciliation}

Strikingly, three articles were submitted that tackles the ever-important topics of forgiveness and reconciliation.

Contributing to the academic discourse of processing forgiveness, Daniël Louw argues that reconciliation is not an instant event, but a process. Forgiveness starts with selfacknowledgement and should manifest in modes of compassionate being-with and diaconal acts of reaching out, creating spaces of 'mystical encounters'. Louw argues that the notion of 'anagnorisis', as captured by narrating the encounter between Joseph and his brothers, should be read as an exemplification of reconciliation, directed by the missio Dei, promissio Dei and passio Dei.

Indicating that overwhelming feelings of resentment and revenge by individuals in emotionally wounded and traumatised communities inflicted by injustice, violence and oppressive systems, often become a way of life, and people seldom deal with forgiveness in their healing process, Rudy Denton explores a process of spiritual healing and life fulfilment that relates to a forgiveness process. This process includes koinonia and diakonia as indispensable elements on the road to reconstructing communities and individuals following conflict and violence.

Eugene Baron and Rantoa Letšosa discuss the role that liturgy could play as an anti-racist praxis. By defining liturgy in a broad sense, not only to refer to the liturgical elements of a worship service but also to the liturgy of life, they argue that liturgy within the church service context, but especially with what happens outside in life, can play a crucial role in helping Christians to become anti-racist. The article provides a discourse analysis on the journey of two reformed denominations, on how they could, through the liturgy of life, establish an anti-racist praxis.

\section{Peace}

Two articles address the quest for peace.
Chris van der Walt posits that in theology the general perception exists that peace entails the absence of war and strife. He argues that when such a perception is measured against what the prophets Isaiah and Micah teach about it, a different reality is sketched. He investigates the concept of peace in Isaiah and Micah, by firstly describing the 'loss of peace' in these two books, and proceeds by showing how peace was returned. He observes that Isaiah and Micah do not describe peace in terms of the absence of a modality such as war, but in terms of relationships. Peace emanates from a relationship that begins with God and which is then lived in a relationship with fellow humans.

Francois Viljoen also deals with the pursuit of peace. He postulates that a country such as South Africa, burdened by violence and intolerance where many citizens claim to be Christians, a call to a Christian ethics of peacemaking is appropriate. He explores the instruction of the Matthean Jesus, that his followers should be peacemakers amidst an intolerant society. The point of departure is taken from the seventh beatitude, 'blessed are the peacemakers, for they will be called sons of God' (Mt 5:9), and proceeds by following the motif of peacemaking through in the rest of the Sermon on the Mount and then contextualises it within the broader Matthean narrative. Based on this investigation, the article offers pastoral guidelines on how Christians should conduct themselves within a violent and intolerant environment.

\section{Pastoral and apologetical issues and developments}

Five articles deal with pastoral and apologetic issues and developments.

Albert Coetsee contributes to the arsenal of studies aimed at addressing the phenomena of the decline in church membership numbers in the Western church and dwindling faith commitment. This he does by presenting the solutions deduced from a single biblical book, namely the book of Hebrews. Coetsee argues that the book of Hebrews is one of the most fitting biblical books to shed light on how the phenomena can be addressed, as Hebrews was written to a church that experienced a decline in faith commitment. The article determines what solutions the writer of Hebrews proposes for addressing his addressees' dwindling in their faith commitment, and then reflects on how the writer's solutions can be applied in the 21st century church.

Amanda du Plessis deals with the changes in pastoral care and counselling and pastoral theology since the middle of the 20th century. She investigates important paradigm shifts during this period by attending to the development of practical (and the subdivision, pastoral) theology; current challenges facing pastoral theology; paradigmatic positions, scientific research markers and approaches, and different layers of meaning unique to pastoral theology; and to 'diakonia' with a religious consciousness of transformative 
moral or ethical orientation. The article contributes to the epistemological dialogue of practical theology.

Steve le Roux and George Lotter aim to demonstrate how the utilising of spiritual coping strategies could help Christians to cope with stress from a faith perspective. Effective coping strategies were explored while the 'BelieveBelong-Behave' pastoral model was proposed. The authors suggest that this pastoral model demonstrates how faith in God could be used to cope with stress more effectively.

Fazel Freeks raises the concern that fathers find themselves increasingly in social crises, while being misrepresented in various studies. He argues that fathers were once considered as pillars of their families, but society at large has begun to grapple with father absence. This decline in active fatherhood, has caused numerous social problems. The article provides mentoring guidelines from a biblical perspective to minimise the effects of absent fathers and to restore relationships within broken families. Freeks argues that these guidelines can be used to mentor fathers to become great assets to families and society.

Jonker Venter and Henk Stoker argue the need for apologetic equipment already in pre-school catechesis. Christian children are exposed not only to a Christian worldview, but also to other dominating worldviews. This exposure can have a negative effect on them. The Bible instructs believing parents to educate their children from an early age with the necessary foundational tools and resources. Venter and Stoker propose that sufficient apologetic and catechetical resources should therefore be provided to parents and educators of these children. These catechetical materials should guide young believers on how to defend themselves among other worldviews.

We wish Gert all the best with his retirement (although we doubt whether the true meaning of the word 'retire' exists in his vocabulary) and pray that the Lord keep on using him in his service for the sake of the church. 